\title{
THE ROLE OF FETAL MOVEMENT AMOUNT ON PREDICTING THE NON- STRESS TEST RESULTS
}

\author{
Murat Gokhan KINAS ${ }^{1}$, Selda Demircan SEZER ${ }^{2}$, Hasan YUKSEL ${ }^{2}$, Ali Riza ODABASI ${ }^{2}$, Mevlut TURE ${ }^{3}$ \\ ${ }^{1}$ Department of Gynecology and Obstetric, Etimesgut Military Hospital, Ankara, Turkey \\ 2 Department of Gynecology and Obstetric, Faculty of Medicine, Adnan Menderes University, Aydın, Turkey \\ 3 Department of Statistics, Faculty of Medicine, Adnan Menderes University, Aydın, Turkey
}

\section{SUMMARY}

Objective: To find a boundary value for the number of fetal movements in pregnant women gestation week $\geq 32$ and to reduce unnecessary nonstress test (NST) applications.

Patients: 171 pregnant women gestation week $\geq 32$

Material and methods: NST was performed to the pregnant women after their fetal movements were counted within an hour while at rest. NST results (NST category 1-normal, NST category 2-suspicious and NST category 3-abnormal) above and below the boundary value were compared.

Findings: When $\leq 5$ cut-off point for number of fetal movements is used, NST category 1, in 22 cases (16\%); NST category 2 in 7 patients (23\%), respectively. When cut off $\geq 35$ is used, NST category 1 in 20 patients (13\%) and NST category 2 in 6 patients (20\%) were detected. Limit the number of fetal movement 16 fetal movements / hour is taken (median value) in group 1 (fetal movement count <16) abnormal NST (category 2 and 3) rate of 19.8\% and in group 2 (the number of fetal movements $\geq 16$ ) of abnormal NST rate (category 2 and 3) was 15.9\%. These results were similar between the two groups ( $p>0.05)$.

Result: No significant differences in NST results were observed between group 1 and group 2. Therefore it is difficult to make a prediction about the reactivity of the NST by considering the number of fetal movements. Fetal movement counts can be misleading. Although not statistically significant, the quantitative tendency makes us think that it is more important to take care of the pregnant women with decreased fetal movement count rather than trusting the excess amount of the fetal movements.

Key words: fetal movement count, non-stress test, tests of fetal well-being

Journal of Turkish Society of Obstetrics and Gynecology, (J Turk Soc Obstet Gynecol), 2011; Vol: 8 Issue: 4 Pages: $238-43$

\section{FETAL HAREKET SAYISININ NONSTRES TEST SONUCUNU ÖNGÖRMEDEKİ YERİ}

\section{ÖZET}

Amaç: $\geq 32$ hafta gebelerde fetal hareket sayısı ile ilgili bir sınır değer saptayarak gereksiz Nonstres test (NST) uygulamasinı azaltma.

Planlama: Prospektif çalışma.

Ortam: Adnan Menderes Üniversitesi Tıp Fakültesi Hastanesi Kadın Hastalıkları ve Doğum Kliniği

Hastalar: $\geq 32$ hafta 171 gebe olgu

Girişim: Olgulara 1 saat boyunca istirahat halinde fetal hareket sayımı sonrası NST çekildi

Değerlendirme parametreleri: Fetal hareket sayısı sınır değerin altında ve üstünde olan gebelerde, NST kategori

Address for Correspondence: Dr. Murat Gökhan Kinaş. Etimesgut Asker Hastanesi, Etimesgut, Ankara Phone + 90 (533) 9627717

e-mail: gokhankinas@hotmail.com

Received: 09 February 2011, revised: 31 July 2011, accepted 11 August 2011, online publication: 23 August 2011 
1-normal, NTS kategori 2-şüpheli ve NST kategori 3-anormal sonuçların karşılaştırılmast.

Sonuç: Fetal hareket sayısı $\leq 5$ kesim noktası alındı̆̆ında, NST kategori 1, olguların 22'sinde (\%16); NST kategori 2, olguların 7'sinde (\%23) bulundu. Kesim noktasl $\geq 35$ alındı̆̆ında ise NST kategori 1 olguların 20'sinde (\% 13) ve

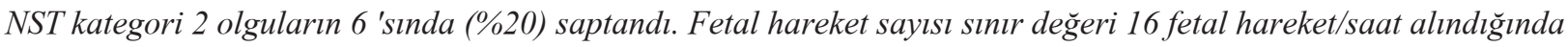
(median değer) grup 1'de (fetal hareket sayıs <16) anormal NST oranı (kategori 2 ve 3) oranı \%19,8 ve grup 2'de (fetal hareket sayısı $\geq 16$ ) anormal NST oranı (kategori 2 ve 3) \%15,9 saptandı. Bu iki grup arasında sonuçlar benzerdi $(p=0.05)$.

Yorum: Fetal hareket sayısı belirlediğimiz değerlerin altında ve üstünde çikan gebelerin, NST sonuçlarında anlamlı bir fark bulunmamıştır. Fetal hareket sayısı dikkate alınarak NST reaktivitesi konusunda öngörüde bulunmak zordur. İstatistiksel olarak saptanmasa da sayısal eğilim fetal hareket sayısının fazlalığına güvenmekten çok, azlı̆̆ durumunda dikkatli olunması gerektiği yönünde düşündürmektedir.

Anahtar kelimeler: fetal hareket sayımı, fetal iyilik hali testleri, nonstres test

Türk Jinekoloji ve Obstetrik Derneği Dergisi, (J Turk Soc Obstet Gynecol), 2011; Cilt: 8 Sayl: 4 Sayfa: 238-43

\section{INTRODUCTION}

The aim of obstetric application is to decrease perinatal mortality to the lowest possible level. This is made possible by prenatal follow-up. Fetal movement count and non-stress test (NST) are the methods used for the determination of fetal well-being $(1,2,3)$.

Fetal movement follow-up is in the form of a test which is easy to perform and quite informative (stimulant) having the potential to be performed at all hours of the day and night by the mother, by herself without the need for any assistance from the clinician or specialized equipment ${ }^{(1,3)}$. Although there are numerous protocols used to estimate fetal movements, the required (ideal) period for the estimation of the optimal number of movements cannot be defined ${ }^{(3,4)}$.

A great many NSTs are applied with different indications for pregnant women in medical centers. As a consequence, time, labor and money are lost. The aim of this study is to investigate the effect of the number of fetal movements estimated via the maternal count method before NST on NST results. An additional aim is to decrease the number of unnecessary NST applications via determining a "boundary value" related to the number of fetal movements for NST application by using the results obtained from this study.

We encountered no previous studies in existing literature aiming to predict NST reactivity by number of fetal movements. Additionally, the National Institute of Child Health and Human Development (NICHD) published a new guide (3-tier interpretation system for heart rate) in 2008 related to NST terminology (5). In this study, fetal heart tracings are estimated according to the guide published by NICHD in 2008 not previously used in existing literature for this objective.

\section{MATERIAL AND METHODS}

A total of 171 pregnant women who got in contact with Adnan Menderes University Medical Faculty Department of Obstetrics and Gynecology Pregnant Policlinic at gestation week $\geq 32$ and NST indication are included in this study. At the beginning of the study, Adnan Menderes University Medical Faculty Hospital Ethics Committee approval was procured. Criteria for the selection of women with respect to the scope of this study were gestation week $\geq 32$, singleton pregnancy, satisfyingly long ( $\geq 20$ minutes) record of fetal heart rate (FHR) and voluntary participation.

The monitorization of fetal heart rate was performed either with Contec fetal monitor CMS 800G (Contec Medical System, China) or Wallach Sonicaid Team (Wallach Surgical Devices, USA) by using an external ultrasonographic transducer. Fetal heart rate tracings were estimated using '3-tier fetal heart rate classification system of NICHD published in 2008 for FHR'. According to this system: Category I was for normal FHR pattern, Category II for suspicious and Category III for abnormal FHR pattern. Tracings in this study were classified as

Category I, Category II and Category III. 
The fetus movement count of all women included in this study needed to be counted within an hour while at rest before NST application. FHR tracing of each case was recorded at least 20 minutes after obtaining the fetal movement number (counting result). Moreover, body mass index (BMI), obstetric and systemic medical histories, problems (preeclampsia, eclampsia, gestational diabetes mellitus etc.) occurring at the gestation period and smoking histories of all patients were obtained (recorded).

In this study, boundary values were mapped out for fetal movement number (count). Five and 35 were chosen as cut-off points. In addition, cases were divided into groups of 16 , which is median. The women for whom the number of fetal movements was below median were chosen as Group 1 and those that were over were placed in Group 2. The NST reactivity of these two groups was estimated with respect to the 3-tier fetal heart rate classification for the FHR guide of the NICHD 2008. Furthermore, the number of fetal movements of a pregnant women was also analyzed with respect to their NST reactivity. As a secondary goal, the effects of maternal properties on the number of fetal movements and NST reactivity were investigated.

The "SPSS 12.0 for Windows" program was used for the estimation of statistical analysis. Descriptive statistics (average \pm standard deviation, median and percent values) were defined for numeric variables. The Mann-Whitney U test, Student-t test, Ki-square test and Pearson correlation test were used for analysis of data. The level of statistical significance was accepted as $\mathrm{p}<0.05$.

\section{RESULTS}

Two cases with fetal movement number of forward [Y1]cut-off value in NST category 1 were excluded from the study. A total of 169 pregnant women were included in this study. Women in the scope of this study have the age average of $27.7 \pm 4.7$, gestation period (week) average of $36.1 \pm 3$., fasting period average of $254 \min \pm 240$, and nulliparous and multipara numbers of $90(53.3 \%)$ and $79(46.7 \%)$ respectively.

The distribution of pregnant women (a total of 19 cases) included in this study in terms of systemic disease existing before pregnancy as the number of women having hypertension, hypothyroidism, hyperthyroidism, hypertension and diabetes mellitus is expressed as 10,3,5 and 1 respectively. The distribution of pregnant women (a total of 44 case) in terms of complications occurring at gestation period as the number of women having gestational diabetes mellitus (GDM), preeclampsia, gestational hypertension, polyhydramnios, oligohydramnios, intrauterine growth retardation, GDM and oligohydramnios, GDM and preeclampsia, GDM and oligohydramnios and preeclampsia is expressed as 19, 9, 4, 2, 2, 3, 2, 2 and 1 respectively. When the number of fetal movements per hour is analyzed with respect to gestation period (weeks), it is observed from the 32 nd week to term that the amount of fetal movement is decreased significantly $(\mathrm{p}=0.014)$, (Graph $\mathrm{I})$.

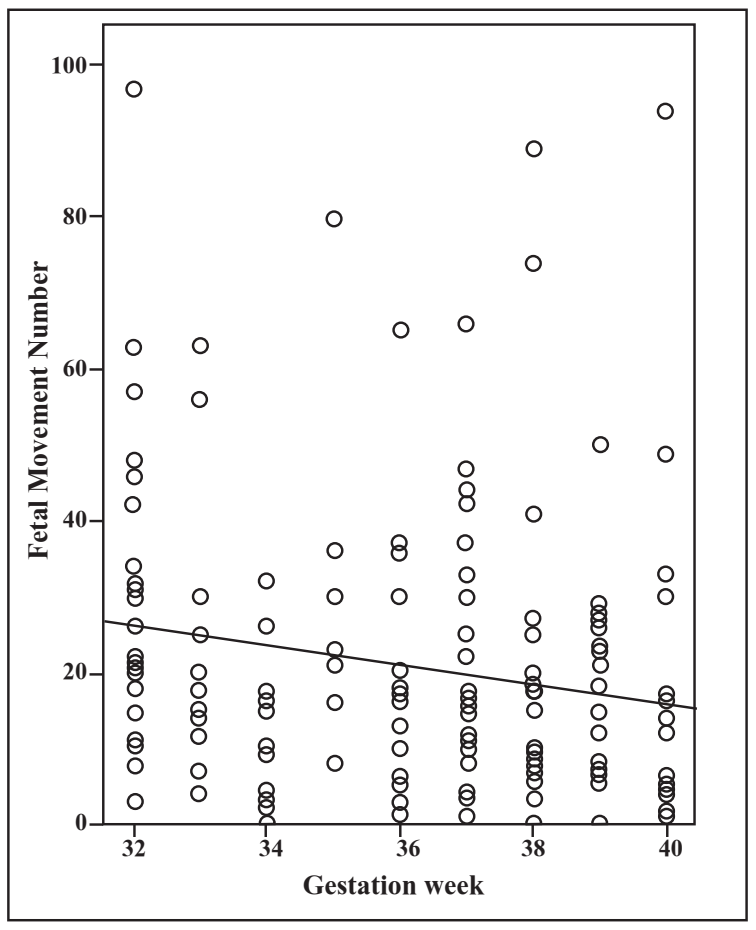

Graph I: Distribution of fetal movement amount with respect to gestation week.

When the fetal heart rate tracings of 169 pregnant women were evaluated, the NST results of 139 cases as Category 1, the tracings of 28 cases as Category 2 and the tracings of two cases as Category 3 were determined. Two pregnant women in tracing category 3 were transferred to Category 2 . In total, the number of pregnant women in Category 3 was 30 . The distribution of pregnant women according to the NST categories was determined as $139(82.2 \%)$ cases for NST Category 1 and $30(17.8 \%)$ cases for NST Category 2. 
There was no significant difference observed between groups having tracings of Category 1 and 2 in terms of age, average gestation week, parity, fasting period, systemic diseases, pregnancy complication and number of fetal movements $(\mathrm{p}>0.05)$. The distribution of NST categories according to the maternal properties and number of fetal movements is given in Table I.

Table I: The distribution of NST categories with respect to maternal properties and number of fetal movements.

\begin{tabular}{|c|c|c|c|c|}
\hline & $\begin{array}{c}\text { Category } 1 \\
\mathbf{n}=139\end{array}$ & $\begin{array}{c}\text { Category } 2 \\
\mathbf{N}=\mathbf{3 0}\end{array}$ & $\begin{array}{r}\text { Total } \\
n=169\end{array}$ & $\mathbf{p}$ \\
\hline Age average & $28 \pm 4,6$ & $26,1 \pm 4,7$ & & 0.932 \\
\hline $\begin{array}{l}\text { Gestaion week } \\
\text { (average } \pm \mathrm{SD} \text { ) }\end{array}$ & $36 \pm 3,1$ & $36,7 \pm 2,4$ & & 0.141 \\
\hline \multicolumn{5}{|c|}{ Movement (number/h) } \\
\hline (median) & n(\%) & $n(\%)$ & & \\
\hline $\begin{array}{c}\text { Gestation week } \\
<37 \mathrm{hf} \\
\geq 37 \mathrm{hf}\end{array}$ & $\begin{array}{l}63(82,8) \\
75(81,5)\end{array}$ & $\begin{array}{l}13(17,1) \\
17(18,8)\end{array}$ & $\begin{array}{l}76 \\
92\end{array}$ & 0.817 \\
\hline $\begin{array}{l}\text { Parity } \\
\qquad \begin{array}{l}\text { Nulliparaous } \\
\text { Multipara }\end{array}\end{array}$ & $\begin{array}{l}75(53,9) \\
64(46,1)\end{array}$ & $\begin{array}{l}15(50) \\
15(50)\end{array}$ & $\begin{array}{l}90 \\
79\end{array}$ & 0.694 \\
\hline $\begin{array}{l}\text { Fasting } \\
\text { (min) average } \pm \text { SD }\end{array}$ & $253 \pm 243$ & $261 \pm 233$ & & 0.645 \\
\hline $\begin{array}{c}\text { Systemic Disease } \\
\text { No } \\
\text { Yes }\end{array}$ & $\begin{array}{c}121(87,1) \\
17(12,3)\end{array}$ & $\begin{array}{c}28(93,3) \\
2(6,7)\end{array}$ & $\begin{array}{c}149 \\
19\end{array}$ & 0.376 \\
\hline \multicolumn{5}{|l|}{$\begin{array}{l}\text { Gestation } \\
\text { coplication }\end{array}$} \\
\hline $\begin{array}{l}\text { No } \\
\text { Yes }\end{array}$ & $\begin{array}{c}106(76,3) \\
33(23,7)\end{array}$ & $\begin{array}{l}19(63,3) \\
11(36,7)\end{array}$ & $\begin{array}{l}125 \\
44\end{array}$ & 0.143 \\
\hline
\end{tabular}

A total of 169 pregnant women who measured fetal movement for an hour were analyzed with the aim of determining the lowest cut-off value for the amount of fetal movement. When the number of fetal movements is determined for 5 cut-off points, NST Category I was observed for 22 cases (16\%) and NST Category II for 7 cases (23\%) at that cut-off value and below[Y2]. Although these results are as expected, this difference is not accepted as significant. It is thought that this result may be due to the fact that the case numbers decreased at that cut-off point. When the cut-off point is determined as $\geq 35$, NST category 1 was observed for 20 (13\%) cases and NST category 2 for $6(20 \%)$ cases. The median was designated as the lowest boundary for the number of fetal movements $(<16$ fetal movement/1 hour) and two groups were organized as low amount of fetal movement $(<16$ fetal movement/1 hour) (group 1) for 84 cases (50\%) and normal amount of fetal movement ( $\geq 16$ fetal movement/1 hour) (group 2) for 85 cases (50\%). No significant difference was observed between these two groups in terms of age, parity, fasting period, the existence systemic pregnancy diseases and pregnancy complication ( $p>0.05)$. However, the gestation weeks of pregnant women in Group 1 were significantly high as compared with those of Group $2(\mathrm{p}=0.003$ and $p=0.011$ ). The distribution of these groups in terms of maternal properties is given in Table II.

Table II: The distribution of groups in terms of maternal properties.

\begin{tabular}{|c|c|c|c|c|}
\hline & $\begin{array}{c}\text { Group } 1 \\
\mathrm{n}: 84\end{array}$ & $\begin{array}{c}\text { Group } 2 \\
\text { n:85 }\end{array}$ & Total & p \\
\hline $\begin{array}{l}\text { Age average } \\
\text { (average } \pm \mathrm{SD} \text { ) }\end{array}$ & $27,7 \pm 3,9$ & $27,6 \pm 5,3$ & - & 0.847 \\
\hline $\begin{array}{l}\text { Gestation week } \\
\text { (average } \pm \mathrm{SD} \text { ) }\end{array}$ & \multicolumn{3}{|c|}{ Gestation week } & 0.003 \\
\hline & $n(\%)$ & $n(\%)$ & & \\
\hline \multicolumn{5}{|l|}{$\begin{array}{l}\text { Gestation week } \\
\text { groups }\end{array}$} \\
\hline$<37$ week & $28(35)$ & $48(54,5)$ & 76 & 0.011 \\
\hline$\geq 37$ week & $52(65)$ & $40(45,5)$ & 92 & \\
\hline $\begin{array}{l}\text { Fasting }(\mathrm{min}) \\
(\text { average } \pm \mathrm{SD})\end{array}$ & $233 \pm 234$ & $274 \pm 246$ & - & 0.266 \\
\hline \multicolumn{5}{|l|}{ Parity } \\
\hline Nulliparaous & $40(49,4)$ & $50(56,8)$ & 90 & 0.333 \\
\hline Multipara & $41(50,6)$ & $38(43,2)$ & 79 & \\
\hline \multicolumn{5}{|l|}{ Systemic Disease } \\
\hline No & $69(87,5)$ & $80(90,1)$ & 149 & 0.189 \\
\hline Yes & $11(13,5)$ & $8(9,1)$ & 19 & \\
\hline \multicolumn{5}{|l|}{ Gestation } \\
\hline \multicolumn{5}{|l|}{ kcomplication } \\
\hline No & $61(75,3)$ & $64(72,7)$ & 125 & 0.391 \\
\hline Yes & $20(24,7)$ & $24(27,3)$ & 44 & \\
\hline
\end{tabular}

Group 1 :Fetal movement number $<16 /$ hour

Group 2 :Fetal movement number $\geq 16 /$ hour

When the effect of Group 1 and 2 on NST reactivity is examined, there is no significant difference observed in terms of NST categories $(\mathrm{p}=0.514)$. The distribution between Groups and NST categories are given in Table III.

Table III: Analysis of groups with respect to NST categories.

\begin{tabular}{lllll}
\hline \multirow{2}{*}{ NST } & \multicolumn{5}{c}{ Fetal Movement Number* } & \\
& Group 1 n & Group 2 n & Total n & p \\
\hline Category 1 & $68(80,2)$ & $71(84,1)$ & 139 & 0.514 \\
Category 2 & $16(19,8)$ & $14(15.9)$ & 30 & \\
\hline
\end{tabular}

*Group 1: <16/hour and Group 2: $\geq 16 /$ hour 


\section{DISCUSSION}

Maternal perception for fetal movements is an old and favored method for determining fetal well-being $(6)$. Despite there being a great deal of methods used for fetal movement count, optimal number of movements, count method, and ideal period necessary for this are not defined. There is no consistent data related to the efficiency of fetal movement count in predicting fetal well-being either.

Several fetal imaging methods were compared by four randomized controlled trials by which fetal movement count methods were compared, and by the meta-analysis of 71.370 cases $^{(7)}$. There was no information obtained from the studies on the necessity of the efficiency of fetal movement number and the necessity of usage of it in fetal imaging. Consequently, there is not enough evidence to propose or dispute fetal movement count in all pregnant women or just risky ones. It was deduced that there was inconclusive information in respect to the usefulness of fetal movement count, and in this regard prospective studies are needed.

Although there are plenty of studies about the 'boundary value' of the fetal movement number, there is no agreement in existing literature on fetal movement count method and its perinatal results $(7)$. Additionally, it is difficult to compare these studies with each other, because fetal movement count methods and fetal movement number cut-off value definitions of each study are different from each other ${ }^{(8)}$. In addition to these, in literature, estimation methods of fetal heart rate tracings for each study are different from each other. In this study, FHR is estimated by using the '3-tier FHR interpretation system of the NICHD 2008 guide. Furthermore, there is no study in literature on the estimation of FHR tracings according to this guide.

In this study, fetal movement count was not compared with other methods, and additionally, an investigation of the relation with the perinatal results is not intended. Furthermore, there is no study similar to this the methods in this study in literature in terms of boundary similarities as well as count method. However, there are a great number of studies performed on fetal movement count method, efficiency of these methods, decreased fetal movement definition.

It is reported by most of the studies that pregnant women with reduced fetal movement have bad perinatal results compared with pregnant women without NST analysis and count ${ }^{(9-11)}$.

The abnormal NST ratio was determined as $8.2 \%$ by a study ${ }^{(10)}$ performed with 2601 pregnant women who experienced a decreasing in fetal movement, and $13 \%$ by another study(11) performed with 2374 pregnant women. A comparison of this result with a control group was not performed for this study. It was observed in this study that the abnormal NST (Category 2) ratio of pregnant women (Group 1) with reduced fetal movement was $19.8 \%$ (if the boundary was 16 fetal movements/hour) and of pregnant women (Group 2) with normal fetal movement it was $15.9 \%$.

The results of these two groups are similar. We interpreted the result as possibly being dependent on the limited number of cases, difference in fetal movement count method, and estimation of FHR tracings via a different method. In this study, FHR tracings were estimated according to the '3-tier FHR interpretation system of the NICHD 2008 guide. In contradistinction to other studies, the number of fetal movements of patients classified as NST Category 1 and 2 were estimated considering the median value. However, no difference was observed between the two groups. In addition, there was no difference observed between pregnant women who were defined as NST Category 1 and 2 by comparison in terms of maternal properties.

In this study, there was no significant difference observed between pregnant women of group 1 and 2 in terms of age and parity in accordance with the literature. There was no significant difference observed these two groups by comparison in terms of systemic diseases and complications occurring in the gestation period. The reducing effect of long-lasting fasting on fetal movements depending on hypoglycemia is well known ${ }^{(12)}$. In this study, there was no significant difference observed with regards to fasting in terms fetal movement number and NST results. Meanwhile, in accordance with literature ${ }^{(13-}$ 17), decreasing of fetal movement number was observed from the 32 nd week to term. In addition, the gestation week was significantly high for the group with decreased fetal movement.

There are great numbers of studies performed to determine the affectivity of fetal movement count on perinatal results. There are differences in this study in terms of fetal movement count methods, NST tracing estimation means and case numbers. It is thought that these differences affect the results. In addition, because there is no control group in this study, there is a 
difficulty in data accuracy on the prediction of NST reactivity of fetal movement number. Failing to achieve homogeneity in terms of the properties of pregnant women included in this study and count conditions is underlined as failure of the studies.

Fetal movement imaging, which is one of the tests assessing fetal well-being, is a test performed easily. However, positive predictive value is low, negative predictive value is high, as with other tests estimating fetal well-being. There are several fetal movement methods developed from the first studies until today, but a standard count method and optimal time period required cannot yet be defined. Low positive predictive values of fetal movement count sometimes render the application of advance methods redundant. NST is one of these advance methods. The prediction of fetal movement count method on NST reactivity should be high to obtain a decrease in NST application. In the study performed with this aim, 'several values of 1 hour fetal movement count' were determined as the boundary value, and the prediction of these values on NST was investigated. However, there was no significant difference observed for NST results of pregnant women having fetal movement numbers below or above these cut-off values.

As a conclusion, longitudinal long term studies about this subject, containing more cases are required. Prediction by using this information about NST reactivity considering fetal movement number is quite difficult. It is thought that due to numerical tendency, although it is not observed statistically, caution is needed in the case of a low number of fetal movements instead of relying on high value fetal movement numbers.

\section{REFERENCES}

1. Uludağ S, Gezer A. Fetusun iyilik halinin belirlenmesi. Klinik gelişim 2008; cilt: 21 / No:1

2. Signore C, Freeman RK, Spong CY. Antenatal Testing-A Reevaluation. 2009 by The American College of Obstetricians and Gynecologists. Published by Lippincott Williams \& Wilkins. 2009; vol. 113, no. 3 .

3. Mangesi L, Hofmeyr GJ. Fetal movement counting for assessment of fetal wellbeing. Cochrane Database of Systematic Reviews, Issue 3, 2009

4. Frøen JF, et al. Manegement of decrease fetal movement
Semin Perinatol 2008; 32: 307- 11

5. Robinson B, MPH, Nelson L. A Review of the Proceedings from the 2008 NICHD Workshop on Standardized Nomenclature for Cardiotocography. Update on Definitions, Interpretative systems with management strategies, and research priorities in relation to intrapartum electronic Fetal Monitoring. Rev Obstet Gynecol. 2008; 1(4): 186- 92.

6. Saastad E, Ahlborg T, Frøen JF. Maternal awareness towards fetal activity associated with SGA. J Midwifery Womens Health 2008.

7. Freeman RK. Problems with intrapartum fetal heart rate monitoring interpretation and patient management. Obstet Gynecol 2002; 100: 813- 26.

8. Heazell AE, Green M, Wright C, et al. Midwives' and obstetricians' knowledge and management of women presenting with decreased fetal movements. Acta Obstet Gynecol Scand 2008; 87: 331- 9 .

9. Havercamp AD, Thompson ME, McFee JR. The evaluation of continuous fetal heart rate monitoring. Am J Obstet Gynecol 1976; $125: 310$

10. Navot D, Yaffe H, Sadovsky E. Diagnosis of fetal jeopardy by assessment of fetal movement and heart rate accelerations. J Perinat Med 1983; 11(3): 175- 8

11. Sadovsky E, Polishuk WZ. Fetal heart rate monitoring in cases of decreased fetal movement. Int J Gynaecol Obstet 1976; 14(3): 285- 8 .

12. Valentin L, Marsal K. Pregnancy outcome in women perceiving decrease fetal movement. Eur J Obstet Gynecol Reprod Biol 1987; 24: 23- 32.

13. Groome LJ, Swiber MJ, Bentz LS, et al. Maternal anxiety during pregnancy: effect on fetal behavior at 38 to 40 weeks of gestation. J Dev Behav Pediatr 1995; 16: 391- 6 .

14. Tveit JVH, Saastad E, Bordahl PE, Stray-Pedersen B, Froen JF. The epidemiology of decreased fetal movements. Proceedings of the Norwegian Perinatal Society Conference Bodo, Norway, 2006.

15. Holm Tveit JV, Saastad E, Stray-Pedersen B, Børdahl PE, Frøen JF. Maternal characteristics and pregnancy outcomes in women presenting with decreased fetal movements in late pregnancy. Acta Obstet Gynecol Scand 2009; 88(12): 1345- 51.

16. Tuffnell DJ, Cartmill RS, Lilford RJ. Fetal movements; factors affecting their perception. Eur J Obstet Gynecol Reprod Biol 1991 May 10; 39(3): 165-7.

17. Ahn MO, Phelan JP, Smith CV, Jacobs N, Rutherford SE. Antepartum fetal surveillance in the patient with decreased fetal movement. Am J Obstet Gynecol 1987 Oct; 157 (4 Pt 1): $860-4$ 